\title{
The Category of Recens and Pure-Mindedness in Józef Bańka's Axiological Reflection
}

\author{
Paweł Nierodka \\ The General Jerzy Ziętek Silesian School of Management
}

\begin{abstract}
I systematize thoughts within the scope of Józef Bańka's philosophical system known as recentivism. I analyze the axiology of recentivism in two categories: recens (i.e., "now") and pure-mindedness. Also, I differentiate among pure-mindedness, which is a quality of homo euthyphronicus (i.e., pure-minded man), simplicity, which is a quality of homo simplex (i.e., simple man), and complexity, which is a quality of homo technicus (i.e., technical man). Moreover, I present different meanings of pure-mindedness which form the basis for reflection in the axiology of recentivism, i.e., the ethics of pure-mindedness, euthyphronics, and esthetics. Then, I use these meanings of pure-mindedness to define the attitude of homo euthyphronicus. Homo euthyphronicus is a man who seeks balance between simplicity and complexity in the modern world, which is highly complex and full of civilization-related threats, while stressing the importance of axiological values.
\end{abstract}

Keywords: simplicity, complexity, pure-mindedness, the present, axiology

\section{Introduction}

Following Georg Wilhelm Friedrich Hegel's philosophical system, such systems became a subject of criticism, which is common in today's philosophy. The "quest for wisdom" as part of a comprehensive perspective on different aspects of reality, which dates back to Greek philosophers (Plato), is evaluated negatively. ${ }^{1}$ However, as paradoxical as it may be, new philosophical systems continue to emerge.

One example of a contemporary philosophical system is Józef Bańka's recentivism. The system is a whole based on axioms, not aspectivity, which is typical of the scientific approach. The axiom-or arché - of recentivism is recens (meaning "now," "fresh"), i.e., the shortest current moment which is new on every occasion. This system's axiology includes a unity of recens (i.e., "now") and pure-mindedness. Pure-mindedness is a notion closely related to simplicity, which has always been pursued by philosophy in this incredibly complex world. Pure-mindedness is characterized by obviousness, once discovered by René Descartes in his philosophical reflection. It is a quality of epistemology, which the author of recentivism classifies outside of axiology. Pure-mindedness is the spontaneity of certainty, which is different from naive realism. ${ }^{2}$ Certainty is a secondary quality of a pure-minded act of intellect. Pure-mindedness is related to clarity, transparency, obviousness, direct cognition, and feeling. ${ }^{3}$ Above all, pure-mindedness is an axiological category, an intuitively reliable sense that helps distinguish between beauty and ugliness or good and evil. The

Paweł Nierodka, Ph.D., The Faculty of Social and Technical Sciences, Institute of Pedagogy, The General Jerzy Ziętek Silesian School of Management, Poland; main research field: Modern Ethical Concepts, Philosophy of Culture, Philosophy of Civilization, Philosophy of Technology, Philosophical Anthropology, and Cultural Anthropology. 
definition of pure-mindedness is the answer to the following question: Who is man as a subject? Man as a subject is a pure-minded man, which involves, among others, being honest, truthful, and having a clear conscience. Pure-mindedness is a sphere typical only of the human species.

In this paper, I attempt to systematize recentivism. I systematize definitions of pure-mindedness, which has not been done by the author of recentivism so far. I focus primarily on one part of the system, i.e., axiology. When analyzing the axiology of recentivism, I refer to the category of recens and, above all, the category of pure-mindedness.

\section{Recens-The Axiom of the Recentivistic System}

Recentivism excludes the repeatability and predictability of human experience. Everything appears "fresh," for the first time, so "nothing can be perceived as already present or predicted to appear in the future; it can only be seen as happening for the first time, "now"' (Bańka 2004, Vol. 1, 28). Although many philosophers had discussed the present, it has not been the arché, the main axiom of philosophical reflection, until recentivism. The idea of "now," i.e. recens, is present in different parts of the recentivistic system, including ontology, epistemology, esthetics, social philosophy, and ethics. ${ }^{4}$ In terms of ontology, Bańka notes that all of existence, which he refers to as "occurrence," exists "now." In terms of the theory of cognition, he claims that the description of every phenomenon is only true in the present time. In terms of esthetics, he talks about experiencing beauty "now." In terms of social philosophy, he discusses threats occurring when societies live in their past or future and forget about the present time. When it comes to ethics, he claims that man makes moral choices at a specific current moment in life and that "man can describe a phenomenon as 'moral' or 'immoral' only within the scope of "now" (Bańka 2003, 253).

Bańka's philosophical system is anthropocentric because the basis for reflection is man, who as a being—or, more precisely, "a subjective occurrence"—is recens, i.e., "now." Although man can keep reliving the past memories or imagining the future, man should, above all, focus on the present as all of existence is found there. Man as a being exists only "now," though in terms of consciousness man can live in each of the three dimensions of time, i.e., the present (awareness of the current moment), the future (imagined moments that are yet to come), and the past (memories of moments that have passed). By highlighting the importance of the present, "recentivism aims to restore man's ability to see the world in an uncontaminated way, i.e., see it 'for the first time' (a recentiori)" (Bańka 1997, 293), "fresh," in every fleeting moment—recens (i.e., "now"). However, if man lives in the past or keeps imagining the future instead of living here and now, if man prefers the former two dimensions of time over the present and forgets about it, man lives a pseudo-life and the present dimension of time is blurred and passes by unnoticed. Nonetheless, recentivism does not negate the past and the future but it explains the threats caused by giving them preference over the present.

The present occurs in every single moment of man's life. Man can create their life only in the present because that is where man is - not in the past, not in the future. The current moment of reality is the instant without which there is no man, for man is the present. "Now is myself-this is the key thesis of the metaphysics of recentivism" (Bańka 1992, 17). Man makes choices within the scope of "now." In recentivism, man who lives in the present and focuses on the present is called homo recens, i.e., present man. Only such a man can be homo euthyphronicus, i.e., pure-minded man who acts currently "according to the simplest (basic) principles" (Bańka 1997, 285). ${ }^{5}$ However, a pure-minded man is not homo simplex, just like the notion of pure-mindedness is not synonymous with the notion of simplicity. 


\section{Pure-Mindedness-An Introduction to the Issue of Recentivistic Axiology}

\subsection{Simplicity vs. Complexity}

The notion of "simplicity" is found in various languages (Greek haplotes, ${ }^{6}$ Latin simplicitas, French simplicité, German Einfachheit). It has different meanings, depending on culture; it is a matter of science, including physics, chemistry, and psychology as well as a matter of religion (Christian, for example). Above all, it is a matter of philosophy. The notion of simplicity is even present in the concepts of ancient (e.g., Aristotle) and medieval philosophers (e.g., St. Augustine, St. Anselm, St. Thomas Aquinas, and Duns Scotus). The latter speak of God's simplicity (simplicitas Dei). It is also a subject of reflection in modern (René Descartes) and contemporary philosophy (Lviv/Warsaw school of thought). In philosophy, simplicity is discussed within the scope of, for example, metaphysics, epistemology, esthetics, ethics, and philosophical anthropology.

In the context of man in modern civilization, simplicity defines the attitude of homo simplex, among others. Homo simplex is a simple, uncomplicated man having problems adapting to the changing technological environment. In the expression homo simplex, the word "simplex" means simple, natural, non-artificial, regular, although it has many different meanings, e.g., "honest, sincere, open” (Kumaniecki 1996, 460). For homo simplex, i.e., simple man, the development of civilization is unclear, incomprehensible, while the civilization environment is a foreign environment. This is a simple man without skills necessary to function more or less efficiently in a technological environment, to survive and be successful in it. It is not only about having "access" to new technologies, but also - and above all - about having the ability to effectively navigate a world that is becoming more and more dominated by new technology and digital reality. Homo simplex symbolizes the attitude of exclusion which denies man the possibility of benefiting-more or less effectively-from civilization-related advancements that become more and more connected with various aspects of human life. The opposite of homo simplex is homo technicus, i.e., technological man, who sees the advancement of civilization as an opportunity to gain new possibilities and is exceptionally well adapted to modern civilization, which is complex in terms of technology and information. Such man has the so-called "sense of technology." The human nature in this is case involves the ability to build tools, which today have a variety of forms (computers, airplanes, etc.).

The issue of simplicity is accompanied by the issue of complexity. These two categories are particularly important in modern civilization. Today, the choice based on the principle of either/or — discussed by, among others, St. Augustine and Søren Kierkegaard (Kierkegaard 1982) - refers to the issues of simplicity and complexity. As a choice between the lack and the overabundance of technical skills, between being homo simplex and being homo technicus, this choice is highly risky in modern world. On the one hand, the attitude of homo simplex leads to "alienation" as it excludes man from everyday life, whose essential, or even intrinsic, element is the advancement of civilization. On the other hand, not all technical skills typical of homo technicus are important in life; some lead to numerous threats and even "alienation" in terms of man's psychological and moral spheres (Spitzer 2013).

Despite symbolizing the attitude of a man who prioritizes complexity (technological complexity), homo technicus has an alternative, a choice. Such man may either use the possibilities offered by technological civilization $^{7}$ or limit — to a various extent - its complexity, thus nearing simplicity. However, when simplicity occurs in man's life, it is always secondary to complexity because that man experienced complexity first. Homo technicus may also seek points of balance between simplicity and complexity in civilization. One example of 
such a balance is translating the internal structural complexity of modern technical devices into a rather simple, external method of handling them. Meanwhile, the attitude of simplicity typical of homo simplex is not a matter of free choice but it results from the life of a man who is unable to keep up with the development of civilization. In this case, the choice between simplicity and complexity — if available at all —is the choice of external help required to understand the complexity of technical/IT devices. Homo simplex is unable to keep up with the advancement of civilization on their own and that is why they need help from others.

Simplicity and "complexity need each other" (Maeda 2007, 7). ${ }^{8}$ When discussing man's pursuit of simplicity and analyzing the laws of simplicity (Maeda 2007, 7-89), John Maeda highlights the importance of a counterpoint in the form of complexity, without which we would not be able to recognize simplicity and appreciate its significance. He notes, however, that there are certain complex things which should not be simplified, including relationships with close ones as well as works of art.

Complexity and simplicity are two symbiotic qualities... each needs the other - its respective definition depends upon the other's existence. To realize a world of complete simplicity would mean that complexity would have to become completely eradicated. And with only simplicity remaining, how would you know what is truly simple? Thus, failing to achieve simplicity is an important service to humanity. (Maeda 2007, 76)

On the other hand, the "excessive" complexity of modern civilization is a threat to human existence.

Simplicity and complexity may be linked not only to technical devices, but also to man's psychological and moral spheres. The important question today is: how does the complexity of civilization bring about complications in the psychological and moral spheres of man's life? It is the question that leads to the idea of pure-mindedness found in recentivism.

\subsection{Pure-Mindedness and Its Meanings}

Pure-mindedness is what defines the attitude of homo euthyphronicus, i.e., pure-minded man, who is different from homo technicus and homo simplex. In the context of civilization, pure-mindedness is the "second naivety," which one reaches at some point. Meanwhile, simplicity—as represented by homo simplex —is the "first naivety." A pure-minded man is not defined by simplicity understood as the lack of technical skills. Such man stresses the importance of technological advancement, adopts its achievements and, at the same time, indicates the threats accompanying this advancement. A pure-minded man's knowledge is often close to that of homo technicus. A pure-minded man accepts the necessary internal complications of technical devices and, simultaneously, underlines how important the external simplicity of their use is. Such man advocates the simplification of complex technical solutions, just like homo technicus. Pure-mindedness is, above all, the simplification of complex things when they cause complications in man's psychological and moral spheres. This is the first meaning of pure-mindedness. The second meaning refers not so much to "Ockham's razor," a tool for reduction, as to a more precise tool, i.e., "axiological sieves." simplify civilization's tools, thus changing their complex form into something simpler (i.e., the first meaning of pure-mindedness), but to sift the advancement of civilization through axiological values, which in fact also results in simplicity. The function of "axiological sieves" is to reject unnecessary complications typical of modern civilization which pose a threat to man. They are not used to "give man new qualities but to defend the values without which such quality would certainly be questionable, i.e., to defend the privacy and intimacy of personal life before the invasion" (Bańka 2003, 203) of the impure-minded man during technological revolutions. The first meaning of pure-mindedness defines a pure-minded man as someone who simplifies their 
civilization-related environment and changes what is not so much complex as it is causing complications due to its complexity, giving it a simpler form. The second meaning of pure-mindedness defines a pure-minded man as someone who uses axiological tools, i.e., "axiological sieves," to selectively eliminate the unnecessary complexity of civilization, which causes complications in man's psychological and moral spheres.

In order to understand the ideal of a pure-minded man put forward in recentivism, one must understand the meanings of pure-mindedness. The notion of pure-mindedness is unclear and leaves room for further analyses and clarifications. It is the basic notion in recentivistic axiology, which is consequently called the axiology of pure-mindedness. The different definitions of this notion correspond - to various extents - to the branches of the above-mentioned axiology, i.e., the ethics of pure-mindedness, euthyphronics (the ethics of civilization), and esthetics.

The third meaning of pure-mindedness is closely related to the notion of obviousness. However, it is different from the obviousness concerning external objects, which is shaped by verification and falsification of different studies, scientific experiments, and everyday experiences. Today, one example of an empirically verifiable obviousness for man is the fact that "Earth is round," though in the past the statement that "Earth is flat" was obvious. Thanks to science, it turns out that some obvious matters are not obvious at all. Our logicalness stems from our sense of obviousness. Although certain things seemed logical in the past, like the flat Earth example, they no longer are. When it comes to the issue of obviousness in recentivism, it must be stressed that it is primarily related to axiological values. Pure-mindedness is "an intuitively reliable sense of understanding life, which is not based on scientific premises. The intuitive understanding of good and evil... defines the obligation of fulfillment and stimulates one's readiness to act in accordance with their values" (Bańka 2001, 324). Pure-mindedness is an "axiological intuition," allowing differentiation between good and evil or beauty and ugliness. Thanks to its reliability, it is a kind of internal "axiological obviousness" when it comes to values such as good and beauty. This obviousness is connected with the direct, intuitive understanding of values. By stressing the importance of pure-mindedness in ethics, for example, recentivism criticizes "theoretical ethics," "the ethics of rationalistic systems," i.e., various metaethics and their complicated language of notions. First, man is required to learn the categories of language they create, and only then man can use them to understand what morality is. Unlike "theoretical ethics," recentivistic ethics stresses Socratic nativism. It highlights how important the directness of experience and understanding of values are. Such an approach to values is different from hermetic, complicated ethical discussions which create a distance between man and values. A pure-minded man understands values in an intuitive, direct, "simple" way, i.e., without the help of complex, complicated "theoretical ethics." The problem with the reliability of this axiological intuition is in its notional/rational definition. The currently analyzed meaning of pure-mindedness is not inference-based. Man arrives at the meaning of something but it is not the result of reasoning. ${ }^{10}$ A pure-minded man is someone who has not lost their "axiological intuition." 11

The fourth meaning of pure-mindedness indicates a good, harmonious unity of man's emotional sphere (thymos) and intellectual sphere (phronesis). The word euthyphronicus, meaning pure-mindedness, is a combination of three notions: eu (good), thymos (emotions), and phronesis (intellect). In modern civilization, the emotional sphere is at risk due to the domination of the intellectual sphere. In order to ensure the balance between the two spheres, what needs to be promoted nowadays is, above all, the sphere of human emotions. According to this meaning of pure-mindedness, the pure-minded man is characterized by a unity or, more precisely, a harmonious development of the two spheres: thymos and phronesis. The lack of such harmony may 
be manifested not only by the domination of phronesis, but also by the domination of thymos.

The fifth meaning of pure-mindedness indicates that in man's life it is important to be able to see the right in values (intellectual pure-mindedness) and to feel the obligation to act in line with them (moral pure-mindedness). According to this meaning, pure-mindedness is a unity of moral pure-mindedness and intellectual pure-mindedness. Intellectual pure-mindedness is, above all, "an intellectual attitude which allows one to see the right in values, regardless of whether these values are fulfilled. The basic assumption of intellectual pure-mindedness is that values may exist without practice" (Bańka 2004, Vol. 1, 24), for example in the world of pure social information. Intellectual pure-mindedness "refers to the ideal obligation where nobody questions whether one should act this way or another" (Bańka 2004, Vol. 2, 118). Meanwhile, moral pure-mindedness "is an imperative to act which, if not followed, brings about consequences and makes one feel guilty" (Bańka 2004, Vol. 2, 118). It is the basic category of ethical reflection in recentivism, the number one principle of conduct and the ultimate criterion for moral judgment. It characterizes people who act in accordance with their values and it is "man's moral ability to act fair, i.e., following what is morally good and avoiding what is morally bad" (Bańka 2001, Vol. 2, 324). Moral pure-mindedness is what defines the moral boundaries of man's freedom. By crossing these boundaries, man becomes immoral, i.e., impure-minded. Moral pure-mindedness "determines" the behavior of moral man, i.e., homo euthyphronicus, internally. This (fifth) meaning of pure-mindedness stresses that in man's life not only the knowledge of values is important, but also the obligation to live by them. However, this approach is far from Socrates' ethical intellectualism because man, despite having the knowledge of good, may not put it into practice. In addition to the knowledge of good, the will to do good is also important. A pure-minded man is "someone who possesses the knowledge of good and is ready to make decisions in accordance with the values they recognize and experience" (Bańka 2000, 376).

The sixth meaning of pure-mindedness is related to, above all, the notion of "simple values." Pure-mindedness is synonymous with these values. The author of recentivism capitalizes them, thus highlighting their importance. What is problematic, however, is finding a criterion based on which these specific values are enumerated instead of others. "Simple values" (pure-minded values) listed by Bańka include:

Goodness. Helpfulness... Honesty... Friendliness. Altruism. Nobleness. Disinterestedness. Kindliness. Gratefulness... Faithfulness. Belief in ideals... Readiness to help others... Dignity. Spiritual integrity. Sincerity... Warmth. Moral integrity... Tenderness. Sociability... Courage. Openness. Practicality... Sympathy. Compassion. Justice... Forgiveness. Perseverance. Eagerness. Steadfastness of principle. Respect for tradition. Respect for parents. Enthusiasm. Ability to love. Clear conscience. Being goal-oriented. Gentleness. Honor... Humanity. Sense of equality. (Bańka 2003, 75)

Someone who lives by these values is referred to in recentivism as pure-minded man. ${ }^{12}$

Although they could be theoretically separated, similar to Aristotle's differentiation between form and matter, the above-mentioned meanings of pure-mindedness constitute a unity within homo euthyphronicus, i.e., pure-minded man. And so: firstly, a pure-minded man is someone who simplifies complex things when they cause complications in man's psychological and moral spheres. Secondly, a pure-minded man is someone who sifts the advancement of civilization through "the sieves of axiological meanings," discarding that which puts the human being at risk in different aspects of existence. Thirdly, a pure-minded man is someone who has an "axiological intuition," allowing differentiation between good and evil or beauty and ugliness. Owing to its reliability, this kind of intuition may be referred to as "axiological obviousness." Fourthly, a pure-minded man has a unity, a harmony of the emotional sphere (thymos), and the intellectual sphere (phronesis). Fifthly, a 
pure-minded man not so much "knows" values, but expresses the willingness to put them into practice. Sixthly, the axiological values known under the general names of "good" and "beauty" adapt a specific form of "simple values" (faithfulness, honesty, sensitivity, etc.) in specific man's life. Out of all the above-mentioned meanings, the most important one is pure-mindedness understood as "axiological intuition." Other meanings of pure-mindedness stem from this meaning (e.g., pure-mindedness understood as a unity of thymos/emotions and phronesis/intellect) or are its tools (e.g., pure-mindedness understood as "axiological sieves"), similar to helmets that protect ice hockey players.

The opposite of a pure-minded man is an impure-minded man, also known as pseudo-man. Each of the above meanings of pure-mindedness has its antithesis in the form of impure-mindedness. Thus, an impure-minded man is a logical opposite of a pure-minded man in these meanings. For example, the impure-minded man puts too much emphasis on either the sphere of phronesis or the sphere of thymos. Despite knowing the axiological values such as good, that man does not live by them and rejects "simple values" (compassion, kindliness, disinterestedness, humanity, etc.), replacing them with a pragmatic approach manifested by the economic calculation of profits and losses. An impure-minded man measures human value based on the value of things, and because things get old quickly (for example, due to the fast technological progress and fashion), that man's relationships with other people are characterized by transience and self-interest.

Summing up, there is a difference between the notion of simplicity understood, among others, as the lack of technical skills typical of homo simplex and the notion of simplicity understood as "pure-mindedness," which is an axiological value synonymous with the "simple values" typical of homo euthyphronicus. One should differentiate between homo simplex and homo euthyphronicus. A pure-minded man seeks harmony between the development of civilization and preserving axiological values. Homo euthyphronicus opposes the advancement of civilization if axiological values are no longer meaningful to man as a result. A pure-minded man also opposes the advancement of civilization if it poses a threat to the psychological sphere by introducing unnecessary complications. It turns out that these threats go unnoticed by the modern homo technicus who, first and foremost, stresses the importance of phronesis (the intellectual sphere) and praxis (the sphere of actions). Today, homo technicus takes, among others, the stance of a principled man and follows primarily the "rules" of economy, regardless of the costs incurred in the sphere of axiological values. Their basic principle is: "I am the principle."

\section{The Axiology of Recentivism}

Pure-mindedness is the axiom of Bańka's axiological reflection. This axiology is based on the aforementioned meanings of pure-mindedness. It includes ethical axiology (ethics of pure-mindedness and euthyphronics) and esthetic axiology (recentivistic esthetics). However, it is difficult to place epistemology within the framework of recentivistic axiology, i.e., to distinguish "epistemological axiology." In recentivism, epistemology is closely related to ontology. Similar to Parmenides, this philosophical system puts a greater emphasis on the unity of being (ontology) and thinking (epistemology) than on identity. Thus, incorporating epistemology into axiology has certain consequences. One of them is arriving at a conviction, i.e., truthfulness, instead of the truth. ${ }^{13}$ 
The ethical axiology of recentivism stresses the importance of both the values that one knows and, above all, the values one puts into practice. The values in this case are not only found in the intellectual sphere (phronesis), but, above all, in the emotional sphere (thymos). Bańka notes that man is a being that may experience remorse and is capable of taking responsibility. Moral pure-mindedness (goodness) is a value in ethical axiology. In recentivism, this axiology is based on two ethical concepts combined by the category of pure-mindedness. The first is called the ethics of pure-mindedness, the other is called euthyphronics. The ethics of pure-mindedness is "a form of pre-axiomatic ethics, which is based on perceptible values that are self-evident due to the accompanying moral guarantee given by people who act in accordance with these values" (Bańka 2004, Vol. 1, 13). It includes the basic moral recommendations for man. It involves discussions on subjects such as human nature and conscience. The ethics of pure-mindedness stresses that "there is a basic agreement among people when it comes to experiencing simple values, which warm indications, appealing to one's emotions, refer to" (Bańka 2002, Vol. 3, 76). Although people may have different views and make different judgments, they fundamentally agree when it comes to their feelings. This is the so-called "warm morality" (Bańka 2002, Vol. 3, 76) connected with the sphere of thymos (emotions), as opposed to "cold morality," typical of praxeology, which is connected, above all, with the spheres of phronesis (mind) and praxis (actions). Meanwhile, the ethics of euthyphronics refers to the same values, i.e., "simple values," as the ethics of pure-mindedness. Both theories share the same understanding of pure-mindedness as "goodness," although in euthyphronics this category is perceived, above all, in the context of the development of civilization and its influence on man. Euthyphronics analyzes man's ethical attitude against a background of the development of a technologically complex civilization. ${ }^{14}$ It opposes the essence of current civilization which promotes the intellectual sphere of phronesis and neglects the emotional sphere of thymos. As the balance between the two spheres is upset, man's intellectual sphere develops more and more, while the development of man's emotional sphere is insufficient. Euthyphronics acts as the ethics of modern civilization and a theoretical treatment of its negative consequences in man's life. The ethics of pure-mindedness is different from the ethics of euthyphronics. Euthyphronics emphasizes the notion of pure-mindedness, meaning first: the simplification of complex things that cause complications in man's psychological and moral spheres; second: "axiological sieves;" and third: a unity of the emotional sphere (thymos) and the intellectual sphere (phronesis). Meanwhile, the ethics of pure-mindedness stresses the importance of pure-mindedness, understood on the one hand as ethical nativism, or "ethical intuition," and on the other - as "simple values." The notions of "simple values" and "axiological intuition" are also found in euthyphronics, although in this case they are not analyzed to such an extent as in the ethics of pure-mindedness. Both concepts of ethics underline the importance of knowledge about values and the realization of these values. The ethical axiology of recentivism has been developed for several decades. The development of euthyphronics has continued since early 1970 s to this date. ${ }^{15}$ Today, the subject of euthyphronics is digital civilization and its influence on man's psychological and moral spheres. It discusses the issue of limits to the development of artificial intelligence and how the digital sphere consistently escapes common man's understanding.

Apart from ethical axiology, which includes two fields - the ethics of pure-mindedness and euthyphronics, recentivism also incorporates esthetic axiology. With such understanding of axiology in mind, Bańka does not include recentivistic epistemology, or more precisely epistemological axiology, in the third volume of his book titled Nowa encyklopedia nauk filozoficznych. Nauka o wartościach (A New Encyclopedia of Philosophical 
Sciences. The Science of Values). He states that the axiology of recentivism, i.e., the science of values, is devoted to three branches:

euthyphronics, the ethics of pure-mindedness, and esthetics... The author uses euthyphronics as justification for the ethics of pure-mindedness... Finally, the objective of esthetics, which the author derives from the idea of recentivism, is to answer the questions that appear in man's life, regardless of the changing esthetic theories. (Bańka 2002, Vol. 2, 3)

What constitutes esthetic axiology is recentivistic esthetics, also known as the esthetics of pure-mindedness. In addition to the category of recens (i.e., "now"), this esthetics also includes the category of pure-mindedness. The esthetic axiology of recentivism highlights the importance of absolute beauty to a given subject, i.e., pure-minded man, who experiences enthusiasm in a moment of recens (i.e., "now"). It concerns a man who is sensitive to beauty in the current moment of life. A pure-minded man experiences beauty (enthusiasm) when man's sensitivity (goodness) meets an object (truth). Beauty is what "sparked" from man's sensitivity and the truth of an object (image, nature, etc.). An object offers a certain truth that man can take, which results in man's enthusiasm (Bańka 1999). Every person has their own sensitivity. Being sensitive to beauty is not "a privilege of a narrow circle of educated people. On the contrary, beauty is... a commonly understood value...; the word "beauty' speaks to all hearts" (Weil 1985, 218-9). What is important here is the current moment in which man experiences the beauty found in a given object (i.e., a thing, another man, or nature). In order to experience beauty, man must "open up" and be sensitive to beauty. Beauty is a synthesis, a unity of goodness and truth. As opposed to the concepts where beauty is defined based on either goodness or truth, the recentivistic esthetics follows the concepts where beauty is the unity of goodness and truth. In addition to the notion of pure-mindedness understood as "axiological intuition," this type of esthetics is closely related to the notion of pure-mindedness understood as a unity of intellectual pure-mindedness (truth) and moral pure-mindedness (goodness), ${ }^{16}$ where moral pure-mindedness is substituted by the notion of goodness and intellectual pure-mindedness is substituted by the notion of truth. Apart from one's esthetic experience, the esthetics of pure-mindedness also stresses the subject of esthetic experience.

It turns out that for the ethical axiology of recentivism (i.e., the ethics of pure-mindedness and euthyphronics) and the esthetic axiology of recentivism (i.e., recentivistic esthetics, also known as the esthetics of pure-mindedness), different meanings of the category of pure-mindedness mentioned in this paper are important.

\section{Conclusion}

The axiology of recentivism includes the unity of recens (i.e., "now") and pure-mindedness. Homo euthyphronicus, i.e., pure-minded man, is homo recens, i.e., present man, who is currently living. One is pure-minded "here" and "now." However, homo recens is not always homo euthyphronicus. Homo recens may also be a pragmatic man, who only pursues economic interest, or a principled man, who prioritizes legal regulations and codes. Pure-mindedness, which is typical of homo euthyphronicus, is different from mathematical simplicity, according to which the simpler things are the more calculations they require. A consequence of mathematical simplicity is the complication of the mathematical method. Meanwhile, in recentivism, "simplicity" is synonymous with "simple values" and the directness of experiencing values with "axiological intuition." It is also synonymous with the unity of thymos (emotional sphere) and phronesis (intellectual sphere) inside of man. In terms of pure-mindedness, "simplicity" is a warning against excessive 
(i.e., threatening to man) complexity of civilization, which causes complications in man's psychological and moral sphere. That is why it is recommended to simplify this complexity of civilization.

However, not everything should be simplified. The oversimplification of man's reality can also result in numerous threats. The axiology of recentivism describes technical complexity and its consequences for man's psychological and moral sphere, but it also points to threats stemming from oversimplification, while stressing the positive results of man's effort. It seeks balance in its approach to modern civilization. What is characteristic of modern society is, on the one hand, the problem of understanding more and more complex technology (e.g., the complex structure of technical/digital devices), and on the other- "the oversimplification paradox," i.e., excessive simplification that does not follow the "principle of moderation" within this scope. If technology makes man's life too simple so that man does not have to make an effort or face challenges, then man lacks satisfaction and does not learn to overcome difficulties. Man loses aspirations and motivations. This may result in the atrophy of the value system as well as creative needs and it may stop further development of personality. Contrary to appearances, effort and creative approach to various everyday situations help man adapt on the psychotechnical level. This approach involves overcoming difficulties, solving problems and commitment. As Bańka stresses, one of the aspects of therapy is to indicate the creative role of problems. Man who does not face problems and does not make an effort to reach their goals, even though the result is often uncertain, loses the need to commit. The author of recentivism highlights the importance of problems in man's life. His philosophical concept "stems from the belief that only the people who notice problems and respond emotionally to immoral deeds, harm, injustice, and violence are deeply affected by beauty and harmony and express their personality" (Bańka 1976, 47).

\section{Notes}

1. Despite the criticism of philosophical systems by, among others, Nicolai Hartmann, who notes that such systems introduce unity at the expense of natural diversity and artificiality at the expense of systematic thinking (Hartmann 1994, 75), the question of a system that would be free of such problems remains open.

2. Pure-mindedness does not rule out the fallibility of senses; it emphasizes the importance of observations.

3. Pure-mindedness is a guarantee for truth, "it involves... such transparency and clarity of truth that the mind is unable to not recognize it... Pure-mindedness is related to a subject's property which forces one to deem a judgment true without the fear of being mistaken, while certainty is only a strong belief that such judgment is true. Certainty is thus a secondary property of a pure-minded act of mind, while pure-mindedness... is the result of 'straight' thinking about a subject" (Bańka 1990, 36). Józef Bańka differentiates not only between pure-mindedness and certainty, but also between internal pure-mindedness and external pure-mindedness.

4. Bańka's philosophical system also includes the following areas: metaphysics, philosophy of man, philosophy of culture, philosophy of technology, philosophy of civilization, philosophy of upbringing, and philosophy of ecology, known as eco-recentivism.

5. Bańka speaks about the simplest, most basic values, such as goodness, altruism, and gratefulness.

6. The Greek word haplotes means not only simplicity, but also sincerity and generosity.

7. Technical skills are not the limits of homo technicus' actions.

8. Murray Gell-Mann is among those who encourage research on relations between simple and complex systems. He believes that results of research on the subject from different perspectives (e.g., physics, biology, humanities, art, behavioral sciences) should be combined (Gell-Mann 1996, 35-36).

9. According to Bańka, "axiological sieves" include: psychological sieves, sociological sieves, pedagogical sieves, information sieves, and esthetic sieves. He also defines "axiological sieves" based on their function, listing for example: reflective sieves, permeating sieves, absorbing sieves, and intercepting sieves.

10. When thinking about pure-mindedness in relation to objects at all, it should be viewed as an approach that is typical of the human species but is rather sensory than rational, i.e., based more on senses than deduction/inference. Pure-mindedness is closely related to the notion of being astonished by reality. 
11. Bańka claims that man is good by nature.

12 In addition to the above-mentioned meanings, pure-mindedness can also be defined based on the "subject" which it relates to, for example: pure-mindedness of view, pure-mindedness of choice, and pure-mindedness of experience.

13. Recentivistic axiology stresses the fact that man can choose values. By choosing values man limits the "freedom" of their actions. At the same time, man should take responsibility for that choice. If choice itself is the "justification" for values, then it is difficult or even impossible to discuss epistemology within the scope of recentivistic axiology. Truth in recentivism is "ontological truth," i.e., the Greek aletheia. It is a matter of discovery, not choice. The possible error in this case is the error of statement on the part of the subject making the statement. One example is Christopher Columbus who discovered America thinking it was a route to India. Thus, error can be made when naming things, not upon discovery. What is important in the naming process is subjectivity. When truth is understood as aletheia, the subject that discovers the truth has to state that "things are as they are" upon discovery. In recentivism, the discovery of truth is the discovery of being, i.e., that which "is" "now."

14. Euthyphronics is the theory of prevention and protection of "simple values which are at risk in a technologically complex civilization" (Bańka 2000, 34).

15. One of Bańka's last books about modern civilization is the work titled Krytyka rozumu cyfrowego. Recentywizm i wielka metamorfoza XXI wieku (The Criticism of the Digital Mind. Recentivism and the Great Metamorphosis of the 21st Century) (Bańka 2014).

16. What is important according to recentivistic/pure-minded esthetics is "the notion of the pure-mindedness of reception and message" (Sośniak 2002, 255).

\section{Works Cited}

Bańka, Józef. Epistemologia jako odkrycie aktualnego momentu prawdy. Próba neosemantyzacji klasycznej definicji prawdy w recentywizmie (Epistemology as the Discovery of the Current Moment of Truth. An Attempt at the Neosemantization of the Classic Definition of Truth in Recentivism). Katowice: Wydawnictwo Uniwersytetu Śląskiego, 1990.

---. Glówne zasady etyki prostomyślności (The Main Principles of the Ethics of Pure-Mindedness). Poznań: Stowarzyszenie Psychologia i Architektura, "Print-B", 2000.

---. Humanizacja techniki. Główne zagadnienia i kierunki eutyfroniki (The Humanization of Technology. The Main Issues and Trends of Euthyphronics). Katowice: Wydawnictwo "Śląsk", 1976.

---. Intelektualizm etyczny Spinozy a etyka prostomyślności (Spinoza’s Ethical Intellectualism vs. the Ethics of Pure-Mindedness). Poznań: Wydawnictwo Stowarzyszenie Psychologia i Architektura, 2000.

---. Krytyka rozumu cyfrowego. Recentywizm i wielka metamorfoza XXI wieku (The Criticism of the Digital Mind. Recentivism and the Great Metamorphosis of the 21st century). Katowice: Wydawnictwo "Śląsk", 2014.

---. Medytacje parmenidiańskie o pierwszej filozofii. Recentywizm i pannyngeneza (Parmenidean Meditations on the First Philosophy. Recentivism and Panningenesis). Katowice: Wydawnictwo Uniwersytetu Śląskiego, 1992.

---. Metafizyka wirtualna. Traktat o strukturach chwilowych (Virtual Metaphysics. A Treatise on Momentary Structures). Katowice: Wydawnictwo Uniwersytetu Śląskiego, 1997.

---. Nowa encyklopedia nauk filozoficznych. Tom 3: Nauka o wartościach (A New Encyclopedia of Philosophical Sciences. Vol. 3: The Science of Values). Poznań: Stowarzyszenie Psychologia i Architektura, 2002.

---. Ojcze nasz, któryś jest teraz. Idee czystej teraźniejszości i teraźniejszościowej filozofii. Tom 2: Zasada antropiczna w filozofii a recentywizm (Our Father Who Art Now. The Ideas of the Pure Present and Present Philosophy. Vol. 2: The Anthropic Principle in Philosophy vs. Recentivism). Katowice: Wydawnictwo Uniwersytetu Ślaskiego, 2001.

---. Stownik pojęć i tekstów filozoficznych. Tom 1: A-N. Przewodnik encyklopedyczny po recentywizmie, eutyfronice $i$ etyce prostomyślności (The Dictionary of Philosophical Terms and Texts. Vol. 1: A-N. An Encyclopedic Guide to Recentivism, Euthyphronics and the Ethics of Pure-Mindedness). Poznań: Stowarzyszenie Psychologia i Architektura, 2004.

---. Stownik pojęć i tekstów filozoficznych. Tom 2: O-Ź. Przewodnik encyklopedyczny po recentywizmie, eutyfronice $i$ etyce prostomyślności (The Dictionary of Philosophical Terms and Texts. Vol. 2: O-Ź. An Encyclopedic Guide to Recentivism, Euthyphronics and the Ethics of Pure-Mindedness). Poznań: Stowarzyszenie Psychologia i Architektura, 2004.

---. Świat poręczenia moralnego. Medytacje o etyce prostomyślności (The World of Moral Guarantee. Meditations on the Ethics of Pure-Mindedness). Katowice: Wydawnictwo Uniwersytetu Śląskiego, 2003.

---. Traktat o pięknie. Studium estetyki recentywistycznej (A Treatise on Beauty. A Study of Recentivistic Esthetics). Katowice: Wydawnictwo Uniwersytetu Śląskiego, 1999.

Gell-Mann, Murray. Kwark i jaguar. Przygody z prostotq i złożonościq (The Quark and the Jaguar: Adventures in the Simple and the Complex). Trans. P. Amsterdamski. Warsaw: Wydawnictwo CIS, 1996. 
Hartmann, Nicolai. Myśl filozoficzna i jej historia. Systematyczna autoprezentacja (Philosophical Thought and Its History. A Systematic Self-presentation). Trans. J. Garewicz. Toruń: “Comer”, 1994.

Kierkegaard, Søren. Albo-Albo. Tom 2 (Either/Or. Vol. 2). Trans. J. Iwaszkiewicz. Warsaw: Państwowe Wydawnictwo Naukowe, 1982.

Kumaniecki, Kazimierz. Stownik łacińsko-polski (Latin-Polish Dictionary). Warsaw: Wydawnictwo Naukowe PWN, 1996.

Maeda, John. Prawa prostoty. We wzornictwie, $w$ technice, $w$ przedsiębiorczości, w życiu [The Laws of Simplicity (Simplicity: Design, Technology, Business, Life)]. Trans. M. Zagrodzki. Warsaw: Wydawnictwa Akademickie i Profesjonalne, 2007.

Sośniak, Tadeusz. "Sztuka-technika—recens (Art-Technology—Recens)." Wieczne teraz. Materiaty z konferencji naukowej "Perspektywy recentywizmu i eutyfroniki" (The Eternal Now. Materials from the Scientific Conference Titled "The Perspectives of Recentivism and Euthyphronics”). Szczyrk, May 2001. Ed. A. L. Zachariasz in cooperation with E. Struzik. Katowice: Wydawnictwo Uniwersytetu Śląskiego, 2002.

Spitzer, Manfred. Cyfrowa demencja. W jaki sposób pozbawiamy rozumu siebie i swoje dzieci (Digital Dementia. What We and Our Children Are Doing to Our Minds). Trans. A. Lipiński. Słupsk: Dobra Literatura, 2013.

Weil, Simone. Myśli (Thoughts). Trans. A. Olędzka-Frybesowa. Warsaw: Instytut Wydawniczy PAX, 1985. 